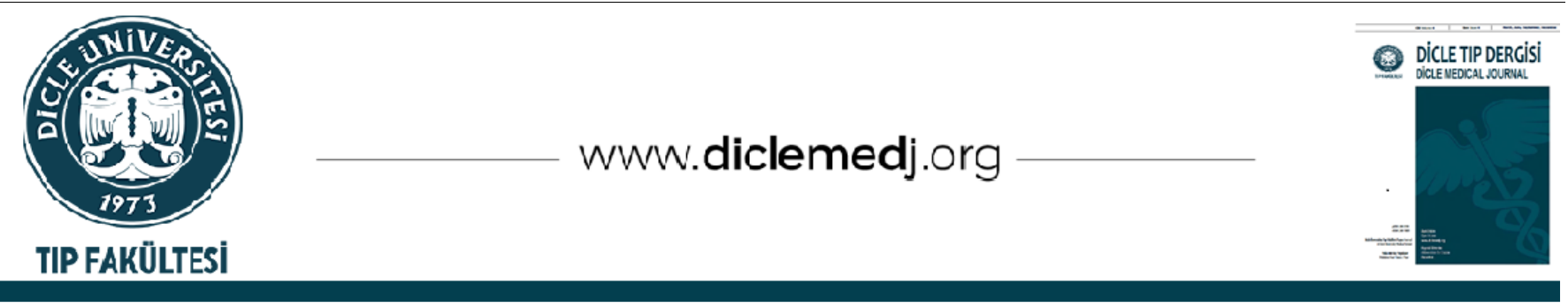

Derleme / Review

\title{
COVID-19 ve Yenidoğan
}

\author{
Sabahattin Ertuğrul ${ }^{\text {D }} 1$, İbrahim Deger ${ }^{D_{1}}$, Sibel Tanrıverdi Yılmaz ${ }_{1}$ \\ 1 Dicle Üniversitesi Tıp Fakültesi, Çocuk Sağlığı ve Hastalıkları Anabilim Dalı, Neonatoloji Bilim Dalı, Diyarbakır, Türkiye \\ Geliș: 10.08.2021; Kabul Tarihi: 29.09.2021
}

Öz

COVID-19 pandemisi dünya çapında yayılmaya devam ederken, risk altındaki popülasyonları belirlememiz ve onları korumak için uygun klinik bakım politikaları geliştirmemiz çok önemlidir.

Yenidoğan SARS-CoV-2 enfeksiyonunun insidansı ve sonuçlarına ilişkin veriler ortaya çıkmaya devam etse de, öğrenilecek daha çok şey vardır. Şimdiye kadar ki kanıtlar, yenidoğanda dikey bulaşmanın nadir olduğunu ve daha büyük bir oranın doğum sonrası solunum damlacıkları yoluyla veya enfekte anne veya bakıcılarla temas yoluyla enfeksiyon kaptığını göstermektedir. Yenidoğanların çoğunda SARS-CoV-2'ye bağlı semptom gelişmez, ancak prematüreliğe bağlı morbiditeler yoğun bakım ve destek gerektirebilir. Semptomların varlığına bakılmaksızın, COVID-19 enfeksiyonundan şüphelenilen veya teyit edilen annelerden doğan tüm yenidoğanlar test edilmelidir. Yenidoğanda COVID-19 durumu hakkında farkındalık, enfeksiyon önleme ve kontrol önlemleri uygulama yöntemleri teşvik edilmelidir.

Anahtar kelimeler: Yenidoğan, COVID-19, SARS-CoV-2

\section{COVID-19 and Newborn}

\section{Abstract}

As the COVID-19 pandemic continues to spread worldwide, it is critical that we identify populations at risk and develop appropriate clinical care policies to protect them.

While data on the incidence and outcomes of neonatal SARS-CoV-2 infection continue to emerge, there is much more to learn. Evidence to date indicates that vertical transmission in the neonate is rare, with a greater proportion contracting postnatally via respiratory droplets or through contact with infected mothers or caregivers. Most newborns do not develop symptoms due to SARS-CoV-2, but morbidities due to prematurity may require intensive care and support. Regardless of the presence of symptoms, all newborns born to mothers with suspected or confirmed COVID-19 infection should be tested. Awareness of the COVID-19 situation in the newborn and methods of implementing infection prevention and control measures should be encouraged.

Keywords: Newborn, COVID-19, SARS-CoV-2

DOI: 10.5798/dicletip.1004151

Yazışma Adresi / Correspondence: Sabahattin Ertuğrul, Dicle Üniversitesi Tıp Fakültesi, Çocuk Sağlı̆̆ı ve Hastalıkları Anabilim Dalı, Neonatoloji Bilim Dall, Diyarbakır, Türkiye e-mail: sertugrul68@yahoo.com 


\section{GíRIŞ}

Yeni koronavirüs 2019 (COVID-19) hastalığından sorumlu olan şiddetli akut solunum sendromu koronavirüsü 2 (SARS-CoV2) adlı virüs, 2019'un sonunda Çin'de yayılmaya bașlamıș ve daha sonra küresel bir pandemiye yol açmıştır. Oluşan bu hızlı süreç, yenidoğanlar gibi belirli popülasyonların yönetiminde, açıklığa kavuşturulması gereken birçok konuyu ortaya çıkarmıştır.

SARS-CoV-2 pozitif annelerden doğan yenidoğanlarda enfeksiyonun klinik özelliklerinin veya pozitif mikrobiyolojik bulguların olmamasına rağmen, dikey maternal-fetal bulaşma tamamen dışlanamamaktadır ${ }^{1}$. Ancak, gebe kadınları taramak, testi pozitif çlkanlara sıkı enfeksiyon kontrol önlemleri uygulamak ve risk altındaki yenidoğanları izlemek çok önemlidir.

Yüksek derecede belirsizliğe rağmen, şüpheli veya doğrulanmış SARS-CoV-2 ile enfekte olmuş annelerin yenidoğanlarının yönetimine ilișkin kılavuzlara ve önerilere duyulan ihtiyaç zorlayıcıdır. Pandeminin ortasında, kanita dayalı kılavuzlar elde etmek zordur, çünkü SARS-CoV-2'nin bulaşma yollarının sağlam, büyük örneklem boyutlu çalışmalara dayalı olarak anlaşılmasını gerektirmektedir. Günümüzde, bu tür veriler mevcut değildir ve var olan veriler genel bilgiler ile sınırlıdır. Bununla birlikte, yenidoğan canlandırmasından, hastane içi ve dışı doğum sonrası bakıma kadar klinik uygulamalara yardımcı olmayı, bilgilendirmeyi amaçlayan ve aynı zamanda emzirmenin yenidoğan bebeklerin korunmasındaki rolünü ele alan fikir birliği beyanları oluşturulmaya çalıșılmaktadır.

$\mathrm{Bu}$ derleme, yenidoğanlarda COVID-19'un önlenmesine rehberlik etmek, SARS-CoV-2'ye maruz kalan yenidoğanların perinatal ve neonatal sonuçlarını tanımlayan mevcut güncel bilimsel kanıtların gözden geçirilmesini amaçlamaktadır.

\section{Yenidoğana SARS CoV-2 Bulaşması}

SARS CoV-2'nin bebeğe anneden bulaşmasının 3 potansiyel mekanizması vardır2. Birincisi, fetus tarafindan yutulan veya solunan amniyotik sividaki transplasental hematojen yayılım veya viral partiküller yoluyla intrauterin bulaşmadır. $\mathrm{Bu}$ bulaş daha az olası görünmektedir, ancak bunun mümkün olduğunu öne süren yayınlar vardır. İkincisi, doğum sırasında annenin enfekte salgılarına veya dışkılarına maruz kaldıktan sonra intrapartum bulaşmadır. Üçüncüsü, enfekte bir anneden, aile üyesinden veya sağlık görevlisinden doğum sonrası bulaşmadır.

\section{Yenidoğanda COVID-19 Perinatal Risk Raktörleri}

COVID-19 şüphesi olan gebe kadınlara (semptomatik veya yakın zamanda pozitif ev teması) SARS-CoV-2 testi için öncelik verilmelidir. Şüpheli/doğrulanmış SARS-CoV-2 enfeksiyonu olan gebe kadınlarda doğumun zamanlaması ve şekli ile anestezi, obstetrik endikasyonlara bağlıdır. Çoğu bilim derneği, annenin klinik koşullarının iyi olması koşuluyla, doğum şeklinin annenin COVID-19 hastalığından bebeğin etkilenmemesi gerektiği konusunda hemfikirdir. Ancak, bu konuda henüz yeterli kanıt bulunmamaktadır. Amerika Birleşik Devletleri'ndeki hastanelerden COVID19 ile enfekte olan gebe kadınlarda \%24-41'lik bir sezaryen oranı bildirilmiștir ${ }^{3}$.

Fetal akciğer olgunluğunu arttırmanın ve anne ölümünü azaltmanın potansiyel faydaları nedeniyle, daha fazla kanit bulunana kadar, erken doğum riski taşıyan enfekte gebe kadınlara antenatal steroidler uygulanmalıdır ${ }^{4}$.

Doğum odası/ameliyathane, kapı kapalıyken bir negatif basınç izolasyon odası olarak işlev 
görecek şekilde donatılmalıdır. Doğum odası içindeki personel, anne-bebek ikilisine bakan temel sağlık çalışanları (1-3 obstetrik ve 1-2 pediatrik klinisyen) ile sinırlandırılmalıdır. Ek personel doğum odası/ameliyathane dışında beklemeli ve gerekirse içeri girmeleri için bir işaret verilmelidir. N95 maske (tercih edilen) veya cerrahi maske (kabul edilebilir) içeren kişisel koruyucu ekipmanları giyip çıkarmadan önce, klinisyenler tarafından dikkatli el hijyeni yapılmalıdır. Gebe kadın cerrahi maske takmalıdır. Ziyaretçiler sadece kadın için gerekli destek kişisi ile sınırlandırılabilir.

Dünya Sağllk Örgütü (DSÖ), COVID-19'lu annelerden doğan yenidoğanlarda kordon klemplenmesinin ertelenmesini ve erken ten tene teması onaylamaktadır5,6. Mevcut kanitlara dayalı olarak bu müdahalelerin artıları ve eksileri tartışıldıktan sonra, ebeveynlerle ortak karar alma teşvik edilir. Gebe bir kadının COVID-19 ile ilgili önemli bir hastalığı varsa ve invaziv mekanik ventilasyon gerektiriyorsa, doğumun yoğun bakım ünitesi ortamında yapılması gerekebilir.

\section{Yenidoğanda Canlandırma}

Yenidoğan klinisyenleri, hastaneye/merkeze özel politikalarına göre doğumlara katılmalıdır. Mevcut veriler, doğum anına yakın SARS-CoV-2 testi pozitif çıan kadınlardan doğan bebeklerin yalnızca \%1,6-2'sinin doğumdan sonraki ilk 1-3 gün içinde pozitif çıktığını göstermektedir. Tüm yenidoğan klinisyenleri önlük ve eldiven giymeli, N95 solunum maskesi ve yüz siperi veya göz koruyucu gözlük veya hava temizleyici solunum cihazı (göz korumalı) kullanmalıdır7.

Yenidoğanın doğumdan hemen sonra aerosol oluşturucu bir prosedür gerektirip gerektirmeyeceği bilinmediğinden, enfeksiyon riskini en aza indirmek için yeterli önlemler alınmalıdır. Doğum odasındaki aerosol üreten prosedürler, T-parçası ve maske ventilasyonu, torba-maske ventilasyonu, entübasyon, aspirasyon, 2 L/dk'nın üzerinde yüksek akışlı oksijen tedavisi, sürekli pozitif hava yolu basıncı (CPAP) ve mekanik ventilasyonu içerir.

Maske ventilasyonu sırasında, iyi bir sızdırmazlık sağlamak ve hava kaçağını azaltmak için maskeyi iki eliyle tutan 1 sağlayıcı ve ikinci kişinin torba-maske ventilasyonu yapması veya T-parça resüsitatörünü yönetmesi ile 2 kişilik tekniği kullanmak daha iyidir. Entübasyon sırasında, klinisyene yönelik riski azaltmak için, videolaringoskop kullanımı düşünülebilir.

COVID-19 pozitif bir kadından doğan bebeğin acil servisten yenidoğan yoğun bakım ünitesine (YYBÜ) veya yenidoğan bakımevine nakli, diğer personellerin minimum düzeyde maruz kalacak șekilde, kapalı bir kuvözde önceden belirlenmiş bir yol izlenerek götürülmelidir.

\section{COVID-19 Olan Annelerden Doğan Term Bebeklerde Emzirme}

Anne sütünün bulaşma yolu olması pek olası değildir. SARS-CoV-2 ile enfekte bir anneden yenidoğana anne sütü yoluyla bulaşabileceğini gösteren geçerli hiçbir ikna edici kanıt yoktur. Bunun yerine; anne sütü, SARS-CoV-2 enfeksiyonuna karşı koruyucu antikorlar sağlayarak faydalı olabilir ${ }^{8}$.

Chambers ve arkadaşları9 viral partiküllerin doku kültüründe replike olamadığı için viral RNA'nın sadece saptanmasının enfektiviteye eşit olmadığını göstermiştir. Son zamanlarda, pandemi sirasinda COVID durumu bilinmeyen 41 anneden alınan insan sütü numunelerinde yüksek oranda SARS-CoV-2'ye karşı salgı antikorlarının olduğu gösterilmiştir ${ }^{10} . \quad \mathrm{Bu}$ nedenle, insan sütünün COVID-19 hastalığına karşı koruyucu bir rolü olabilir. Annenin sağlığı izin veriyorsa, emzirmenin besleyici, immünolojik ve gelişimsel faydaları, bebeklerin tipik olarak hafif hastalığı olduğu düşünüldüğünde, potansiyel bulaşma riskinden daha avantajlı olduğu söylenebilir. 
Yenidoğanların, enfekte olmuş bir anneden veya başka bir bakıcıdan yatay geçiş yoluyla enfeksiyon kapma olasılığı daha yüksektir. Bu nedenle, enfekte bir kişi yenidoğan bir bebek ile temas halinde iken uygun solunum hijyenini ile korumanın önemi daha fazla vurgulanmalıdır. Enfekte bir anne cerrahi maske takmalı, emzirmeden önce ellerini ve gögüslerini sabun ve suyla ylkamalı ve bebeği emzirmelidir. Alternatif olarak, bebek sağlıklı bir bakım sağlayıcı tarafından sağılmış anne sütü ile beslenebilir. Beslemeler arasında, bebeğin beşiği (veya küvözü), enfekte annenin yatağından en az $180 \mathrm{~cm}$ uzağa, tercihen fiziksel bir bariyerin (perde gibi) arkasına yerleştirilmelidir ${ }^{11}$.

DSÖ ve Amerikan Pediatri Akademisi (AAP) dahil olmak üzere hem uluslararası hem de ulusal topluluklar, bu salgin sirasinda emzirmenin korunmasını desteklemektedir ${ }^{12}$.

COVID-19 Olan Annelerden Doğan Term ve Prematüre Bebeklerin Bakımı

SARS-CoV-2'nin dikey geçişi, viremi eksikliği ve anjiyotensin dönüştürücü enzim 2 (ACE-2) ile transmembran serin proteaz 2'nin örtüşmeyen ekspresyonu nedeniyle nadir görünmektedir ${ }^{13}$.

ABD'de doğumların \%1-3'ünde neonatal enfeksiyon bildirilmiştir. COVID-19'lu anneler, anne doğumdan 14 günden daha uzun bir süre önce testi pozitif ise, enfeksiyon olasılığı daha düşüktür ${ }^{14}$. Çalışmalarda, COVID-19 doğumları arasında erken doğum, düşük doğum ağırlığı ve sezaryen başvuruları sıklıkla gözlenmiştir15. Başlangıçtaki inanışların aksine, yenidoğan enfeksiyon oranı vajinal doğum, odada kalma veya emzirme ile $\operatorname{artmamıştır}^{16}$.

YYBÜ'ye solunum sıkıntısı ile kabul edilen erken doğmuş ve zamanında doğan bebekler, potansiyel olarak solunum desteği ve aerosol oluşturan prosedürler (CPAP, endotrakeal entübasyon ve sürfaktan, gibi) gerektirebilir.
Entübasyon, uygun kişisel koruyucu ekipman kullanılarak en deneyimli yenidoğan klinisyeni tarafından yapılmalıdır. Bebekler, ateș, öksürük, burun akıntısı, solunum sıkıntısı, yetersiz beslenme, letarji, kusma, diyare, döküntü ve ödemi içerebilen SARS-CoV-2 enfeksiyonunun belirti ve bulguları açısından yakından izlenmelidir. COVID-19'dan şüphelenilen veya doğrulanmış annelerden doğan tüm yenidoğanlarda doğumdan 24 ve 48 saat sonra (veya 24-48 saatte tek bir test) nazofaringeal, orofaringeal veya nazal sürüntü kullanılarak SARS-CoV-2 RNA'sının ters transkriptazpolimeraz zincir reaksiyonu (RT-PCR) ile test edilmesi önerilir6.

SARS-CoV-2 bağlamında yenidoğan banyosu hakkında az sayıda çalışma bildirilmiş olsa da, yayınlanmış bazı kılavuzlar enfeksiyon yayılma riskini azaltmak amacıyla yenidoğanların hemen yıkanmasını teşvik etmektedir ${ }^{17}$.

AAP kayıtlarında, doğumda izole edilen yenidoğanlar (22/1123; \%2) ve odada kalanlar (21/ 974; \%2,2) arasinda COVID-19 enfeksiyonu riski benzerdi ${ }^{18}$. Çeşitli ulusal, toplum temelli çalışmalardan elde edilen veriler, doğrulanmış veya şüphelenilen SARSCoV-2 enfeksiyonu olan annelerden doğan bebeklerin odaya alınması ve doğrudan emzirilmesinin, uygun temas ve damlacik önlemlerinin alınması durumunda enfeksiyon riskini artırmadığını göstermektedir ${ }^{19}$.

Asemptomatik SARS-CoV-2 pozitif yenidoğanlar yakın takip sağlandıktan sonra hastaneden taburcu edilebilir. Ateş düşürücü almadan 24 saat boyunca ateşi olmayan ve iyileşmekte olan enfekte bir anne, semptomların başlamasından 10 gün sonra bulaşıcı değildir ve bebeğine güvenle bakabilir 6 .

Dicle Üniversitesi Hastaneleri Pandemi Hastanemize Nisan 2019-Mayıs 2021 tarihleri arasında başvuran 18 gebe Covid-19 hastanın bebeği gözlem amacıyla YYBÜ'ye yatırıldı. Bu 
hastalardan 10'u (\%55) prematüre doğmuștu. Bu hastalardan 6'si (\%33) 32. gebelik haftasının altındaydı. Hastalar doğduklarında ve 24 saat sonra COVID-19 için yapılan PCR testleri negatifti. Term bebekler COVD-19'a yönelik 2 testi negatif gelince taburcu edildiler. Prematüre olan bebeklerde, beklenen prematüre morbiditelerinin dişında, olumsuz durum ile karşılaşılmadı, istenen olgunluğa ulaşınca taburcu edildiler. Bu hastaların tümüne anne sütü verildi.

\section{Erken Başlangıçlı Yenidoğan COVID-19 Enfeksiyonu}

Olgunlaşmamış bağışıklık sistemi, maternal IgG antikorlarının pasif transferi ve daha düşük ACE-2 ekspresyonu, yetişkinlere kıyasla bebeklerde ve çocuklarda daha az enflamasyona, daha hafif hastalık ve daha hızlı iyileşme ile sonuçlanabilir20. COVID-19'lu annelerden doğan 100'den fazla yenidoğan vakası tanımlanmış ve çok daha fazlası bildirilmemiş olsa da, virüsün intrauterin bulaşma olasılığı şimdiye kadar hiç şüphesiz doğrulanmamış veya dışlanmamıştır.

Anne doğumdan 14 gün önce veya 2 gün sonra SARS-CoV-2 pozitifse ve doğumdan sonraki ilk 12 saat içinde amniyotik sıvı, plasenta dokusu, yenidoğan kanında veya solunum örneklerinde olduğu gibi, 24 saat sonra yenidoğan kan veya solunum örneklerinde virüs tespit edilmişse, genel olarak, intrauterin bulaşma makul bir şekilde doğrulanabilir ${ }^{21}$. Amniyotik sıvı, plasenta dokusu ve erken neonatal numuneler negatif, ancak 24 saat sonra alınan numuneler pozitif ise virüsün intrapartum veya erken postpartum dönemde edinilmiş olması muhtemeldir.

SARS-CoV-2 pozitif yenidoğanlar klinik olarak izlenmeli ve izole edilmelidir. Daha önce açıklandığı gibi, bu yenidoğanların bakımı sırasında klinisyenler tarafından eksiksiz kişisel koruyucu ekipman kullanılmalıdır. Erken başlangıçlı yenidoğan COVID-19 (hastalığın doğumdan sonraki 2 ila 7 gün arasında başlaması) muhtemelen perinatal bulaşmadan (doğum içi veya daha yaygın olarak doğumdan hemen sonra) kaynaklanır. Enfekte yenidoğanların çoğu ya asemptomatiktir (\%20) ya da burun akıntısı ve öksürük (\%40-50) ve ateş (\%15-45) gibi hafif semptomlara sahiptir ${ }^{22}$. Solunum sıkıntısı (\%12-40), beslenme güçlükleri, letarji, kusma ve diyare (\%30) gibi orta ila şiddetli semptomlar ve çoklu organ yetmezliğinin klinik kanitları da gözlenmiștir ${ }^{23}$. Yenidoğanda COVID-19 enfeksiyonunun laboratuvar kanıtları arasında lökositoz, lenfopeni, trombositopeni ve yüksek inflamatuar belirteçlerin spesifik olmayan bulguları yer alabilir ${ }^{24}$.

Semptomatik COVID-19 pozitif yenidoğanların tedavisi çoğunlukla destekleyicidir. Solunum sıkıntısı için CPAP gibi uygun solunum desteği önerilir. COVID-19 akciğer hastalığından ziyade yenidoğana özgü akciğer patolojisi (surfaktan eksikliği ve mekonyum aspirasyon sendromu gibi) varsa endotrakeal entübasyonun gerekli olması daha olasıdır ${ }^{25}$. Sağlık çalışanlarına aerosolizasyon yoluyla enfeksiyon bulaşma riskini en aza indirmek için, ventilatör devresinin ekspiratuar koluna bir viral filtre yerleștirilebilir.

\section{Geç Başlangıçlı Yenidoğan COVID-19 Enfeksiyonu}

Yenidoğanlarda semptomatik SARS-CoV-2 enfeksiyonlarının tanısının çoğu doğumdan 5-7 gün sonra konur (geç başlangıçlı neonatal COVID-19) ${ }^{23}$. Yenidoğanın, annesinin solunum salgılarına maruz kalması veya enfekte sağlık çalışanları veya evdeki temaslılara maruz kalmasıyla doğum sonrası bulaşma geç başlangıçlı yenidoğan COVID-19 enfeksiyonunda muhtemelen önemli bir rol oynar, ancak anne salgılarına ve vücut sıvilarına intrapartum maruziyet de katkıda bulunabilir².

Yatarak tedavi gerektiren SARS-CoV-2 enfeksiyonlu 61 yenidoğandan oluşan bir 
kohort çalışmasında, hipertermi, burun akıntısı, hafif solunum semptomları, apne, beslenme güçlügü veya kusma ve letarji sık olarak bildirilmiştir ${ }^{23}$. $\quad \mathrm{Bu}$ çalışmada, gögüs radyografileri anormaldi, $\% 56$ 'sında nonspesifik opasiteler ve \%28'inde buzlu cam değişiklikleri (bu hastaların yarısı prematüreydi) ${ }^{23}$. Enfekte yenidoğanların üçte biri solunum desteğine ve ek oksijene ihtiyaç duymuştu. Enfekte yenidoğanların anneleri vakaların \%26'sında SARS-CoV-2 testi pozitifti ve enfekte olmuş yenidoğanların \%52'sinde enfekte bir kişiyle yakın temasa öyküsü vard ${ }^{23}$.

Kötüleşen hastalarda letarji, apne, ateş veya hipotermi, taşikardi, takipne, hipoksemi, hipotansiyon ve buzlu cam opasitelerinin radyografik bulguları bildirilmiştir ${ }^{22}$. Lökositoz, trombositopeni, laktat yüksekliği (\%55), Creaktif protein artışı (\%29) ve lenfopeni (\%9) gözlenmiştir ${ }^{23,26}$. Yaygın damar içi pıhtılaşma da meydana gelebilir.

COVID-19 ile enfekte yenidoğanlar için yönetim destekleyici olmaya devam eder ve ek oksijen, solunum desteği, sıvı resüsitasyonu ve sıcaklık kontrolünü içerir. Şu anda, yenidoğan COVID19 'da antiviral ilaçların ve steroidlerin kullanımına dair kanıt bulunmamaktadır ${ }^{27}$.

1 aydan küçük yaşta, 3 kat daha yüksek yoğun bakıma kabul riski ile ilişkilendirilmiştir28. Sistematik bir incelemede yenidoğanların daha büyük çocuklara (daha büyük çocukların \%3'ünün yoğun bakım ünitesine ihtiyacı vardır) kıyasla daha şiddetli hastalıkları olduğu (enfekte yenidoğanların \%12'sinde) bildirilmiştir ${ }^{29}$.

\section{Yenidoğanda Multisistem İnflamatuar Sendromu}

Çocuklarda multisistem inflamatuar sendrom (MIS-C), çocuklarda COVID-19 enfeksiyonunu takiben yeni bir durumdur ve ateş, yüksek inflamatuar belirteçler ve hem pro- hem de antiinflamatuar sitokinlerin yüksek seviyeleri ile karakterizedir ${ }^{30}$.
MIS-C'li çocuklar sıklıkla kardiyovasküler sistem (şok, sol ventrikül disfonksiyonu, yüksek kardiyak enzimler, koroner arter anormallikleri), gastrointestinal sistem (mide bulantısı, kusma ve gastroenteriti taklit eden diyare veya inflamatuar bağırsak hastalığı) ile ilgili semptomlarla veya Kawasaki hastalığına benzeyen mukokutanöz semptomlarla başvururlar.

Tipik olarak 6 ay ile 5 yaş arasında görülen Kawasaki hastalığının aksine, MIS-C'li çocukların medyan yaşının 5 ila 9 yıl olduğu bildirilmiştir. MIS-C bebeklerde nadirdir ve Hastalık Kontrol ve Önleme Merkezleri, 1 yaşından küçük çocuklarda MIS-C vakalarının sadece \%4'ünü bildirmektedir ${ }^{31}$. Neonatal MIS$\mathrm{C}$ (MIS-N) nadiren bildirilmiştir ${ }^{32}$.

İki haftalıkken testi pozitif olan 49 günlük bir erkek bebekte Mis-C tanısı kondu, bebek intravenöz immünoglobulin ve puls metilprednizolon tedavisi ile tedavi edildi ve ardından iyileşme sağlandı ${ }^{33}$. Akut SARS-CoV-2 enfeksiyonu bulaşan 26 haftalık gebelikte doğan 7 aylık bir bebekte YYBÜ'de ölümcül bir MIS-C vakası bildirilmiştir ${ }^{34}$.

MIS-C gelişimi için risk faktörlerini aydınlatmak ve hastalık şiddetinin öngörücülerini netleştirmek için, 1 yaşından küçük çocuklarda daha fazla çalışmaya ihtiyaç vardır.

\section{COVID-19'a Karşı Așılar}

Yakın zamanda Pfizer-BioNTech ve Moderna tarafından üretilen 2 aşı, acil kullanım izni kapsamında ABD Gıda ve İlaç Dairesi tarafından onaylandı.

Pfizer-BioNTech aşısı, 16 yaş ve üzerindeki bireylere 21 gün arayla $2 \mathrm{doz}$ halinde verilir. Moderna aşısı, 18 yaş ve üzerindeki bireylere 28 gün arayla $2 \mathrm{doz}$ halinde verilir. Her iki aşı da semptomatik laboratuvar onayl COVID-19'u önlemede \%90'dan fazla etkilidir. Kör, randomize, plasebo kontrollü araştırmalar şu anda bu aşıların güvenliğini, immünojenisitesini 
ve etkinliğini incelemek için 12 ila 17 yaşındaki çocuklarla ilgili çalışmalar yapılmakta (NCT04368728) $^{35}$ veya planlanmaktadır (NCT04649151) ${ }^{36}$. Așlların gebe kadınlarda ve çocuklarda güvenliği, SARS-CoV-2'nin yeni ve mutant suşlarına karşı etkinliği ve SARS-CoV2'nin mutant suşlarını hedef alan daha yeni aşılara olan potansiyel ihtiyaç hakkında daha fazla kanit gerekmektedir ${ }^{37}$.

\section{Yenidoğan COVID-19'un Uzun Dönem Etkileri}

SARS-CoV-2 enfeksiyonunun kalıcı öksürük ve nefes darlığı ve kalıcl akciğer iltihabı, bronşektazi, fibroz ve pulmoner vasküler hastalık potansiyeli olan yetişkinlerde uzun süreli etkileri bulunmaktadır. Hiçbir semptomu olmayan veya hafif semptomları olan enfekte yenidoğanlar, enfekte yetişkinlerde gözlenene benzer şekilde açıkça semptomatik hale gelmeden önce muhtemelen değişken bir süre boyunca hipoksemik kalabilirler ${ }^{38}$.

Aslında, yenidoğanlar, virüsün uzun süreli asemptomatik saçlımı ile hava yolu epitellerinde virüsün sessiz taşıyıcıları olabilir ${ }^{39}$. Kronik hava yolu inflamasyonunun, yenidoğanları çocukluk çağı astımına yatkın hale getirerek hava yolunun yeniden şekillenmesine ve kalınlaşmasına neden olabileceği düşünülmektedir.

Vasküler etkiler ve tromboembolizm, yetişkinlerde COVID-19 mortalitesine önemli ölçüde katkıda bulunmuştur ve artmış proinflamatuar sitokinlere, sistemik inflamasyona ve viral replikasyon ve protrombotik duruma yol açan bağlanmadan kaynaklanan endotel hasarına bağlanmıştır. Ek olarak, erken/birinci trimester maternal SARS$\mathrm{CoV}-2$ enfeksiyonlarının fetüs üzerindeki sonuçlarına ilişkin kanıt eksikliği ve erken fetal kayıplar, konjenital defektler ve teratojenisite insidansı henüz araştırılmamıştır. Solunum, kardiyovasküler ve nörogelişimsel sonuçları değerlendirmek için maruz kalan yenidoğanların uzun süreli takibi yapılmalıdır.
Ayrıca, gelecek nesiller üzerindeki psikososyal etkisi anlaşılmayı beklemektedir.

\section{SONUÇ}

Sağlık hizmeti veren klinisyenler için COVID-19 pandemisi sırasında yenidoğan bakımında zorluklar ile karşılaşılmıştır. Bunun nedeni, bu popülasyonların savunmasızlığı, enfekte hastaların yönetim stratejileri ve sonuçlarında yüksek kaliteli kanıt eksikliği, ebeveynlerin bebeklerinden ayrilması veya izolasyon ihtiyacl, enfeksiyon dalgalanmaları sırasında hastane sistemlerinin aşırı yüklenmesi ve yeterli takibin sağlanmasındaki zorluklardır.

COVID-19'un anne ve yenidoğan arasında paylaşılan solunum partikülleri dışında herhangi bir yolla doğum sonrası bulaşma olası görünmemektedir. Anneye erken maruz kalmanın, doğrudan emzirmenin sağladığı yararlar, çok daha önemli destekleyici kanıtlara sahiptir ve bu nedenle, bu uygulamaların yerleșik yararları, yenidoğana viral bulaşma riskinden daha ağır basmaktadır. Doğumda enfekte olan az sayıdaki yenidoğanda bulaşma yolları hakkında daha uzun vadeli takip verileri ve çalışmalara büyük ihtiyaç duyulsa da, SARSCoV-2 ile enfekte annelerden doğan yenidoğanlarda sonuçlara ilişkin ön kanıtlar güven vericidir.

Sonuç olarak, günümüzde yenidoğan COVID-19 sonuçlarına iliş̧kin mevcut verilerin kanıtlarının yetersizliği, SARS-CoV-2 yenidoğan risklerinin daha iyi bilinmesini ve daha güvenilir kanıtların oluşması gerektiğini göstermektedir.

Çıkar Çatışması Beyanı: Yazarlar çıkar çatışması olmadığını bildirmişlerdir.

Finansal Destek: Bu çalışma her hangi bir fon tarafından desteklenmemiştir.

Declaration of ConflictingInterests: The authors declare that they have no conflict of interest. 
Financial Disclosure: No financial support was received.

\section{KAYNAKLAR}

1. Yang P, Wang X, Liu P, et al. Clinical characteristics and risk assessment of newborns born to mothers with COVID-19. J Clin Virol. 2020; 127: 104356. doi: 10.1016/j.jcv.2020.104356.

2. Blumberg DA, Underwood MA, Hedriana HL, Lakshminrusimha S. Vertical transmission of SARSCoV-2: what is the optimal definition? Am J Perinatol. 2020; 37: 769-72. doi: 10.1055/s-00401712457.

3. Khoury R, Bernstein PS, Debolt C, et al. Characteristics and outcomes of 241 births to women with severe acute respiratory syndrome coronavirus 2 (SARS-CoV-2) infection at five New York City medical centers. Obstet Gynecol. 2020; 136: 273-282. doi: 10.1097/AOG.0000000000004025.

4. American College of Obstetricians and Gynecologists. COVID-19 FAQs for obstetriciangynecologists, obstetrics. Available at: https://www.acog.org/clinical-

information/physician-faqs/covid- 19-faqs-for-obgyns-obstetrics. Erişim tarihi; 31 Temmuz 2021.

5. World Health Organization. Clinical management of COVID-19. Available at: https://www.who.int/publications/i/item/clinicalmanagement-of-covid-19. Erişim tarihi; 31 Temmuz 2021.

6. Centers for Disease Control and Prevention. Evaluation and management considerations for neonates at risk for COVID-19. Available at: https://www.cdc.gov/coronavirus/2019-

ncov/hcp/ caring-for-newborns.html. Erişim tarihi; 31 Temmuz 2021.

7. Sankaran D, Nakra N, Cheema R, Blumberg D, Lakshminrusimha S. Perinatal SARS-CoV-2 Infection and Neonatal COVID-19: A 2021 Update. Neoreviews. 2021 May; 22: e284-e295. doi: 10.1542/neo.22-5-e1001.

8. Yang N, Che S, Zhang J, et al; COVID-19 Evidence and Recommendations Working Group. Breastfeeding of infants born to mothers with
COVID-19: a rapid review. Ann Transl Med. 2020; 8: 618. doi: 10.21037/atm-20-3299.

9. Chambers C, Krogstad P, Bertrand $\mathrm{K}$, et al. Evaluation for SARS-CoV-2 in breast milk from 18 infected women. JAMA. 2020; 324: 1347-1348. doi: 10.1001/jama.2020.15580.

10. Demers-Mathieu V, Dung M, Mathijssen GB, et al. Difference in levels of SARS-CoV-2 S1 and S2 subunits- and nucleocapsid protein-reactive SIgM/IgM, IgG and SIgA/IgA antibodies in human milk. J Perinatol. 2021 Apr; 41: 850-859. doi: 10.1038/s41372-020-00805-w.

11. Chandrasekharan P, Vento M, Trevisanuto D, et al. Neonatal resuscitation and postresuscitation care of infants born to mothers with suspected or confirmed SARS-CoV-2 infection. Am J Perinatol. 2020; 37: 813-24. doi: 10.1055/s-0040-1709688.

12. American Academy of Pediatrics. Breastfeeding guidance post hospital discharge for mothers or infants with suspected or confirmed SARS-Co V-2 infection. Available at: https://services.aap.org/en/pages/2019-novelcoronavirus-covid-19- infections/clinicalguidance/breastfeeding-guidance-post-hospitaldischarge/. Erişim tarihi; 31 Temmuz 2021.

13. Edlow AG, Li JZ, Collier AY, et al. Assessment of maternal and neonatal SARS-CoV-2 viral load, transplacental antibody transfer, and placental pathology in pregnancies during the COVID-19 pandemic. JAMA Netw Open. 2020; 3: e2030455. doi: 10.1001/jamanetworkopen.2020.30455.

14. American Academy of Pediatrics. FAQs: management of infants born to mothers with suspected or confirmed COVID-19. Available at: https://services.aap.org/en/pages/2019-novelcoronavirus- covid-19-infections/clinicalguidance/faqs-management-of-infants-born-tocovid-19-mothers/. Erişim tarihi; 31 Temmuz 2021.

15. Smith V, Seo D, Warty R, et al. Maternal and neonatal outcomes associated with COVID-19 infection: A systematic review. PLoS One. 2020; 15: e0234187. doi: 10.1371/journal.pone.0234187.

16. Walker KF, O'Donoghue K, Grace N, et al. Maternal transmission of SARS-COV-2 to the neonate, and possible routes for such transmission: 
a systematic review and critical analysis. BJOG. 2020; 127: 1324-36. doi: 10.1111/14710528.16362 .

17. Poon L, Yang $\mathrm{H}$, Lee J, et al. ISUOG Interim Guidance on 2019 novel coronavirus infection during pregnancy and puerperium: information for healthcare professionals. Ultrasound Obstet Gynecol. 2020; 55: 700-8. doi: 10.1002/uog.22013.

18. Chawla D, Chirla D, Dalwai S, et al. PerinatalNeonatal Management of COVID-19 Infection Guidelines of the Federation of Obstetric and Gynaecological Societies of India (FOGSI), National Neonatology Forum of India (NNF), and Indian Academy of Pediatrics (IAP). Indian Pediatr. 2020; 57: 536-48. doi: 10.1007/s13312-020-1852-4.

19. Knight $M$, Bunch $K$, Vousden $N$, et al. Characteristics and outcomes of pregnant women admitted to hospital with confirmed SARS-CoV-2 infection in UK: National population based cohort study. BMJ. 2020; 369: m2107. doi: 10.1136/bmj.m2107.

20. Rawat $M$, Chandrasekharan $\mathrm{P}$, Hicar MD, Lakshminrusimha S. COVID-19 in newborns and infants-low risk of severe disease: silver lining or dark cloud? Am J Perinatol. 2020; 37: 845-9. doi: 10.1055/s-0040-1710512.

21. Blumberg DA, Underwood MA, Hedriana HL, Lakshminrusimha S. Vertical Transmission of SARSCoV- 2: What is the Optimal Definition? Am J Perinatol. 2020; 37: 769-72. doi: 10.1055/s-00401712457.

22. Dhir SK, Kumar J, Meena J, Kumar P. Clinical features and outcome of SARS-CoV-2 infection in neonates: a systematic review. J Trop Pediatr. 2021; 67: fmaa059. doi: 10.1093/tropej/fmaa059.

23. Gale C, Quigley MA, Placzek A, et al. Characteristics and outcomes of neonatal SARS-CoV2 infection in the UK: a prospective national cohort study using active surveillance. Lancet Child Adolesc Health. 2021 Feb; 5: 113-21. doi: 10.1016/S23524642(20)30342-4.

24. Zeng L, Xia S, Yuan W, et al. Neonatal early-onset infection with SARS-CoV-2 in 33 neonates born to mothers with COVID-19 in Wuhan, China. JAMA Pediatr. 2020; 174: 722-5. doi: 10.1001/jamapediatrics.2020.0878.
25. De Luca D. Managing neonates with respiratory failure due to SARS-CoV-2. Lancet Child Adolesc Health. 2020; 4: e8. doi: 10.1016/S23524642(20)30073-0.

26. Oncel MY, Akın IM, Kanburoglu MK, et al. A multicenter study on epidemiological and clinical characteristics of 125 newborns born to women infected with COVID-19 by Turkish Neonatal Society. Eur J Pediatr. 2021; 180: 733-42. doi: 10.1007/s00431-020-03767-5.

27. Wardell H, Campbell JI, VanderPluym C, Dixit A. Severe acute respiratory syndrome coronavirus 2 infection in febrile neonates. J Pediatric Infect Dis Soc. 2020; 9: 630-5. doi: 10.1093/jpids/piaa084.

28. Swann OV, Holden KA, Turtle L, et al ISARIC4C Investigators. Clinical characteristics of children and young people admitted to hospital with covid-19 in United Kingdom: prospective multicentre observational cohort study. BMJ. 2020;370:m3249. doi: 10.1136/bmj.m3249.

29. Dong Y, Mo X, Hu Y, et al. Epidemiology of COVID19 among children in China. Pediatrics. 2020; 145 : e20200702. doi: 10.1542/peds.2020-0702.

30. Grazioli S, Tavaglione F, Torriani G, et al. Immunological assessment of pediatric multisystem inflammatory syndrome related to COVID-19 [published online ahead of print November 12. J Pediatric Infect Dis Soc. 2020 Nov 12; piaa142. doi: 10.1093/jpids/piaa142.

31. Centers for Disease Control and Prevention. Multisystem inflammatory syndrome (MIS-C): health department-reported cases of multisystem inflammatory syndrome in children (MIS-C) in the United States. Available at: https://www.cdc.gov/mis-c/ cases/index.html. Erişim tarihi; 31 Temmuz 2021.

32. Dufort EM, Koumans EH, Chow EJ, et al; New York State and Centers for Disease Control and Prevention Multisystem Inflammatory Syndrome in Children Investigation Team. Multisystem inflammatory syndrome in children in New York state. N Engl J Med. 2020; 383: 347-58. doi: 10.1056/NEJMoa2021756.

33. Orlanski-Meyer E, Yogev D, Auerbach A, et al. Multisystem inflammatory syndrome in children associated with SARS-CoV-2 in an 8-week old infant. 
J Pediatric Infect Dis Soc. 2020 Dec 31; 9: 781-784. doi: $10.1093 /$ jpids/piaa137

34. Farias ECF, Justino MCA, Mello MLFMF. Multisystem inflammatory syndrome in a child associated with coronavirus disease 19 in the Brazilian Amazon: fatal outcome in an infant. Rev Paul Pediatr. 2020; 38: e2020165. doi: 10.1590/1984-0462/2020/38/2020165.

35. BioNTech/Pfizer. Study to describe the safety, tolerability, immunogenicity, and efficacy of RNA vaccine candidates against COVID-19 in healthy individuals. Clinical trial \#NCT04368728. Available at:

clinicaltrials.gov/ct2/show/NCT04368728. Erişim tarihi; 31 Temmuz 2021.

36. Moderna/Biomedical Advanced Research and Development Authority. A study to evaluate the safety, reactogenicity, and effectiveness of mRNA-
1273 vaccine in adolescents 12 to $<18$ years old to prevent COVID-19 (TeenCove). Clinical trial \#NCT04649151. Available at: https://clinicaltrials.gov/ct2/show/NCT04649151. Erişim tarihi; 31 Temmuz 2021.

37. Lauring AS, Hodcroft EB. Genetic variants of SARS-CoV-2: what do they mean? JAMA. 2021; 325: 529-31. doi: 10.1001/jama.2020.27124.

38. Dhont S, Derom E, Van Braeckel E, Depuydt P, Lambrecht BN. The pathophysiology of 'happy' hypoxemia in COVID-19. Respir Res. 2020; 21: 198. doi: 10.1186/s12931-020-01462-5.

39. DeBiasi RL, Delaney M. Symptomatic and asymptomatic viral shedding in pediatric patients infected with severe acute respiratory syndrome coronavirus 2 (SARS-CoV-2): under the surface. JAMA Pediatr. 2021; 175: 16-8. doi: 10.1001/jamapediatrics.2020.3996. 